\title{
Effects of precommercial thinning on the forest value chain in northwestern New Brunswick: \\ Part 5 - Kraft and Thermomechanical pulping and pulp quality
}

\author{
by Paul Bicho ${ }^{1}$ Elmer Portillo², Bernard Yuen², Dongbo Yan² and Doug G. Pitt ${ }^{3}$
}

\begin{abstract}
Forty-eight years after application, three nominal precommercial thinning (PCT) spacings of $4 \mathrm{ft}(1.2 \mathrm{~m}), 6 \mathrm{ft}(1.8 \mathrm{~m})$ and $8 \mathrm{ft}$ $(2.4 \mathrm{~m}$ ) were compared to an unthinned control in six replicate, balsam fir (Abies balsamea [L.] Mill.)-dominated stands. Following the clearcut harvest of three of these replicates in 2008, chips produced from sawmilling trials (slab-wood) and from the top logs of the sampled trees (top-log) were kraft and thermomechanically (TMP) pulped. In general, top-log chips took longer to kraft pulp, had lower yields, and produced pulps with shorter, finer fibres than the corresponding slab-wood chips, across all PCT treatment levels. The main effects of PCT on pulping occurred with slab-wood chips and not top-log chips. While end-product quality in either kraft or TMP production was generally unaffected by wood from the range of thinnings tested, slight reductions in slab-wood chip density and $\mathrm{H}$-factor suggest that kraft pulping productivity may be reduced by $1.8 \%$ with furnish from thinned stands. While these losses could be offset somewhat by lower chip consumption, the economic benefits for a kraft mill are marginal at best, and sharing of fiscal gains across the fibre value chain needs to be explored. Specific refining energy required in TMP production was, however, reduced by $4 \%$ with furnish from thinned stands. These results suggest that value-chain optimization is ultimately dependent on the segregation of fibre from different sources, including within-tree and among silvicultural treatments and sites.
\end{abstract}

Keywords: precommercial thinning, balsam fir (Abies balsamea), kraft pulping, thermomechanical pulping, pulping efficiency, pulp quality

\section{RÉSUMÉ}

Quarante-huit ans après avoir été réalisés, trois espacements nominaux déclaircie précommerciale de 4 pieds $(1,2 \mathrm{~m})$, de 6 pieds $(1,8 \mathrm{~m})$ et de 8 pieds $(2,4 \mathrm{~m})$ ont été comparés à un témoin non éclairci selon une répétition de six blocs dans des peuplements dominés par le sapin baumier (Abies balsamea [L.] Mill.). Suite à la coupe à blanc de trois de ces répétitions en 2008, les copeaux obtenus lors des essais en scierie (dosses et rognures) et à partir des billes de la partie supérieure des arbres échantillonnés (billes de cime) ont été mis en pâte selon les procédés kraft et thermomécanique. De façon générale, les copeaux des billes de cime ont nécessité une transformation plus longue au cours du procédé kraft, ont généré des rendements plus faibles ainsi qu'une pâte comprenant des fibres plus courtes et plus fines que dans le cas des copeaux correspondant issus des dosses et des rognures et ce, pour tous les traitements déclaircie précommerciale. Les principaux effets de léclaircie précommerciale ont été identifiés dans les copeaux issus des dosses et des rognures et non dans ceux provenant des billes de cime. Même si la qualité du produit final obtenu par le procédé kraft ou thermomécanique était généralement la même pour tout le bois obtenu de lensemble des essais déclaircie, les petites réductions de densité et du facteur $\mathrm{H}$ à partir des copeaux de dosses et des rognures indiquent que la productivité du procédé kraft de mise en pâte pourrait être réduite de 1,8\% lorsque lapprovisionnement provient de peuplements éclaircis. Même si ces réductions pourraient probablement être effacées par une consommation réduite de copeaux, les avantages économiques dans le cas d'une usine kraft sont au mieux marginaux et le partage des gains monétaires tout au long de la chaîne d’approvisionnement se doit dêtre étudié. Cependant, lénergie requise spécifiquement pour le raffinage au cours du procédé thermomécanique a été réduite de $4 \%$ dans le cas des copeaux provenant des peuplements éclaircis. Ces résultats indiquent que loptimisation de la chaine de valeur dépend en fin de compte de la ségrégation des fibres issues de différentes sources, incluant larbre lui-même ainsi que les traitements sylvicoles et les sites.

Mots clés : éclaircie précommerciale, sapin baumier (Abies balsamea), procédé kraft, procédé thermomécanique, efficacité de la mise en pâte, qualité de la pâte

\footnotetext{
${ }^{1}$ Formerly with FPInnovations - 3800 Wesbrook Mall, Vancouver, British Columbia V6S 2L9. Now Canfor Pulp Innovation,\#138-8610 Glenlyon Parkway, Burnaby, British Columbia V5J 0B6. Corresponding author. E-mail: Paul.Bicho@canforpulp.com ${ }^{2}$ FPInnovations 3800 Wesbrook Mall, Vancouver, British Columbia V6S 2L9.

${ }^{3}$ Canadian Forest Service, Canadian Wood Fibre Centre, 1219 Queen St. E., Sault Ste. Marie, Ontario P6A 2 E5.
} 


\section{Introduction}

The precommercial thinning (PCT) trials in the balsam fir ( $A b$ ies balsamea [L.] Mill.)-dominated stands of Green River, New Brunswick (Pitt et al. 2013b), offered a unique opportunity to assess, in a coordinated manner, how PCT affects stand productivity (Pitt et al. 2013c), disease losses (Warren et al, 2013), harvesting efficiency (Plamondon and Pitt 2013) and lumber recovery and quality (Duchesne et al. 2013). This approach enabled the effects of PCT on various stages of the value chain to be evaluated.

Approximately $50 \%$ of the log volume entering a sawmill is converted into chips that are consumed by the pulp and paper sector (Duchesne et al. 2013). This percentage increases if the top portion of a stem is also chipped for pulping. The quality of the fibre in these chips has a direct bearing on the quality, cost, and value of the ensuing pulps. Therefore, no value chain assessment of forest management practices such as PCT is complete without considering how these practices affect pulping and pulp quality.

In kraft pulping studies using sawmill residual chips from PCT in balsam fir, Hussein et al. (2006) discouraged the use of chips from heavily thinned stands (nominal spacings of $2.6 \mathrm{~m}$ ) for kraft pulping because pulps from these stands tend to exhibit slower pulping rates and inferior strength properties relative to pulps from unthinned or moderately thinned stands (nominal spacings of $1.8 \mathrm{~m}$ ). They attributed this comparatively inferior performance to higher levels of juvenile wood and indications of higher levels of compression wood in trees from heavily thinned stands. Furthermore, while thinning improves wood uniformity and increases overall log diameter, it lowers basic wood density (Koga et al. 2002), which can lower mill productivity. In the Green River PCT study, Duchesne et al. (2013) reported that whole disk density decreased linearly with thinning intensity, by as much as $7 \%$. While this may not adversely affect pulp yield, a reduction in wood density can affect pulp productivity and therefore have an economic impact. These are two examples of how PCT may be perceived to adversely affect pulping. However, to determine the overall economic effect across the value chain, one must assess whether a cost in one link of the value chain is offset by a profit in another. Only by viewing these effects holistically, across the entire value chain, can the true economic impact of PCT be properly assessed.

This paper, the fifth in a series, describes how PCT of balsam fir at the Green River trial sites affected both kraft and thermomechanical (TMP) pulping and pulp quality. The data generated in this paper, in conjunction with those presented in the other papers in this series, are used by Pitt et al. (2013a) to assess how PCT affects the full value chain.

\section{Methods}

The Green River PCT trial site is located in northwestern New Brunswick, near the Quebec border. The plots have been thoroughly documented by Pitt and Lanteigne (2008) and Pitt et al. (2013b). Six naturally generated stands of balsam fir were thinned between 1959 and 1960, to three nominal spacing levels of $4 \mathrm{ft}(1.2 \mathrm{~m}), 6 \mathrm{ft}(1.8 \mathrm{~m})$ and $8 \mathrm{ft}(2.4 \mathrm{~m})$. Portions of each stand were left unthinned as experimental control areas. In 2008, three of these stands (considered replicate blocks) were harvested (Plamondon and Pitt 2013) and a sample of 150 stems was processed into lumber (Duchesne et al. 2013). The three stands (blocks) harvested included the Summit Road site, and two Upper Belone sites (Pitt et al. 2013b), resulting in a total of $12 \mathrm{block} / \mathrm{PCT}$ treatment combinations.

\section{Chips for pulping}

Pulping was conducted on residual chips obtained during sawmill trials of the $12 \mathrm{block} /$ treatment combinations described in Duchesne et al. (2013). To ensure representative sampling, over $50 \mathrm{~kg}$ of chips were collected throughout the duration of each run of logs sawn. In addition, the corresponding top-logs (diameter less than 4 in. or $10 \mathrm{~cm}$ ) were chipped separately in a 10-knife, 36-ft Carthage disk chipper. In this study, chips are referred to by their origin within a stem; namely the "top-log" (made by disk chipper) or "slab-wood" chips (sawmill residual chips).

Chip samples from each of the 12 block/treatment combinations were tested for basic wood density and oven-dry moisture content using a modified TAPPI T258 om-02a (TAPPI 1994) water displacement methodology. Bulk density, also known as chip packing density, was determined on air dried chips according to Hatton (1979). Chips for kraft pulping were air-dried and screened through a Wennberg chip classifier to include only those that were $2 \mathrm{~mm}$ to $6 \mathrm{~mm}$ thick. For thermomechanical pulping, chips were screened on a BM\&M (Burnaby Machinery and Mill Equipment Ltd, Vancouver BC), two-deck laboratory chip classifier to remove oversized $(>31 \mathrm{~mm})$ and fine $(<2 \mathrm{~mm})$ material.

\section{Kraft pulping}

\section{Exploratory kraft pulping}

Time/temperature relationships ( $\mathrm{H}$-factor) for kraft pulping were determined in a B-K micro-digester assembly (Keays and Bagley 1970). Three 50-gram air dried subsamples from each well-mixed batch of screened chips were kraft pulped under the conditions outlined in Table 1. Each subsample was pulped at one of the three different $\mathrm{H}$-factors. After pulping, the kappa number (a measure of residual lignin in pulp), pulp yield, and residual effective alkali (REA) were determined. The higher the $\mathrm{H}$-factor (a dimensionless, time-temperature factor), the longer a chip furnish takes to be pulped to a given kappa number. Kappa was measured by TAPPI standard T236 om-99, pulp yields are the ratio of the dried pulp mass produced to the mass of wood used (expressed as a percentage), and REA was determined by titration according to Milanova and Dorris (1994). Pulps were screened through a vibrating, flat screen with $0.2-\mathrm{mm}$-wide slots. Pulp material retained on the screens was considered "rejects", whereas the material that passed through the screens was considered "screened kraft pulp". These were expressed as percentages on oven dried (OD) wood. H-factor vs. kappa number and yield curves were generated and used to determine the pulping conditions needed to generate kappa 30 pulps to produce handsheets for testing.

\section{Large-scale kraft pulping}

Large pulping trials were conducted in a 28L Weverk laboratory digester using the conditions summarized in Table 1 and the $\mathrm{H}$-factors identified via the bomb cooks needed to reach the 30 kappa target. Chips requiring similar $\mathrm{H}$-factors were segregated by containment in individual baskets within the digester during pulping. Each pulp was classified by BauerMcNett (Bauer Bros., Brantford ON) for size distribution and Canadian Standard Freeness (CSF) according to (PAPTAC standard C.1, PAPTAC 2013). Fibre length distribution and coarseness were determined via Fibre Quality Analyzer (FQA) (OpTest, Hawkesbury ON). 
Table 1. Kraft pulping and thermomechanical (TMP) pulping conditions used in testing

\begin{tabular}{ll}
\hline Kraft Pulping Conditions & \\
\hline Time to maximum pulping temperature & $135 \mathrm{~min}$. \\
Ramp to maximum pulping temperature & $1.11^{\circ} \mathrm{C} / \mathrm{min}$. \\
Maximum pulping temperature & $170^{\circ} \mathrm{C}$ \\
H-factors (bomb cooks) & $1300,1600,1900$ \\
Effective alkali (EA) & $16 \%$ (on OD wood) \\
Sulphidity, as \% on active alkali & $26 \%$ (on active alkali) \\
Liquor to wood ratio & $5: 1$ \\
& \\
\hline Thermomechanical (TMP) Pulping Conditions & \\
\hline Plates & Rotor No. 3809 modified \\
& Stator No. 3804 modified \\
Preheater / refiner housing pressures & $152 \mathrm{kPa} / 183 \mathrm{kPa}$ \\
Refiner housing temperature & $135^{\circ} \mathrm{C}$ \\
Chip presteaming time & 10 minutes (atmospheric) \\
Preheater residence time & 10 minutes \\
Pulp consistency & $19 \%-25 \%$ oven-dried pulp \\
Prex compression & ratio $3: 1$ \\
\hline
\end{tabular}

(ANOVA). The pulping and pulp quality of chips made from slabwood and top-log wood were compared, for both types of pulping processes, via a paired- $t$ test and the extent to which differences between the pulping behaviour and pulp quality of the two wood types were influenced by PCT was evaluated. Orthogonal contrasts were used to compare values for the unthinned plots to averages for the thinned, values for the 4 - $\mathrm{ft}$ spacing to averages of the $6-\mathrm{ft}$ and 8 - $\mathrm{ft}$, and values for the $6-\mathrm{ft}$ to those of the 8 -ft spacing. Similarly, orthogonal contrasts were used to compare the unthinned plots to the thinned, and to test for linear and quadratic trends related to thinning intensity for the different effects. Therefore, using contrasts, the effects of PCT on selected properties were determined, and (if significant), the type of trend (linear vs. quadratic) could also be assessed.
The ensuing pulps were refined in a PFI (Noram, Pointe Claire QC) mill (0 rev, 3000 rev, 6000 rev, 12000 rev) according to PAPTAC standard C7. Handsheets were made and tested for strength, surface, and optical properties according to PAPTAC standard methods. Handsheet properties are presented as interpolations at a Canadian Standard Freeness of $300 \mathrm{~mL}$.

\section{Thermomechanical pulping (TMP)}

First-stage refining conditions, through a Sunds Defibrator TMP 300 (Metso, Ville St.-Laurent, QC) single-disc laboratory refiner, are outlined in Table 1 . The resulting high freeness pulps were further refined (second stage) in a $30.5 \mathrm{~cm}$ Sprout Waldron (Muncy, PA) open-discharge laboratory refiner equipped with type D2A507 plates (nominal plate gap $0.03-0.25 \mathrm{~mm}$ ). Each sample was refined to three energy levels to create TMP pulps in the freeness range from $50 \mathrm{~mL}$ to $200 \mathrm{~mL}$ CSF

After latency removal, each pulp was screened on a 6-cut laboratory flat screen and screen rejects were determined. Bauer-McNett fibre classifications and fibre lengths were determined on screened pulps. Handsheets were prepared with white water recirculation to minimize the loss of fines and tested for bulk, physical and optical properties using PAPTAC standard methods.

\section{Statistical analysis}

SYSTAT 7.0 (SPSS Chicago, IL) was used for all statistical analyses. Data sets conformed to the normality, homogeneity of variance, and independence assumptions of analysis of variance

\section{Results and Discussion Differences between slab-wood and top-log chips Quality}

On average, chips from top-logs were about $3 \%$ denser than chips from the matching slab-wood (Table 2). This difference was greatest in trees harvested from the Summit Road replicate. There was little or no effect of PCT on the basic wood density of

Table 2. Least squares means and standard errors (SEs), for basic wood densities $\left(\mathrm{kg} / \mathrm{m}^{3}\right)$, by wood type, site/block, and PCT nominal spacing. Results of ANOVA $(p>f)$ are shown for treatment effects.

\begin{tabular}{|c|c|c|c|c|c|}
\hline \multirow[b]{2}{*}{ Basic Wood Density $\left(\mathrm{kg} / \mathrm{m}^{3}\right)$} & \multicolumn{3}{|c|}{ Slab-wood } & \multicolumn{2}{|c|}{ Top-wood } \\
\hline & $\mathbf{n}$ & Ave & SE & Ave & SE \\
\hline $\begin{array}{l}\text { Grand average } \\
\text { Site average }\end{array}$ & 12 & 322 & 2.4 & 331 & 2.9 \\
\hline Upper Belone 1 & 4 & 327 & 3.7 & 333 & 3.8 \\
\hline Upper Belone 2 & 4 & 321 & 4.7 & 324 & 7.2 \\
\hline Summit Road & 4 & 318 & 3.1 & 336 & 1.4 \\
\hline \multicolumn{6}{|l|}{ PCT } \\
\hline Unthinned & 3 & 329 & 4.5 & 327 & 9.8 \\
\hline $4 \mathrm{ft}$ & 3 & 318 & 3.4 & 331 & 4.5 \\
\hline $6 \mathrm{ft}$ & 3 & 326 & 4.0 & 333 & 5.8 \\
\hline $8 \mathrm{ft}$ & 3 & 315 & 3.2 & 334 & 5.3 \\
\hline \multicolumn{6}{|l|}{ PCT ANOVA $(p>F)$} \\
\hline thinned vs. unthinned & & 0.06 & & 0.52 & \\
\hline $4 \mathrm{ft}$ vs. $6 \mathrm{ft}$ and $8 \mathrm{ft}$ & & 0.64 & & 0.74 & \\
\hline $6 \mathrm{ft}$ vs. $8 \mathrm{ft}$ & & 0.09 & & 0.98 & \\
\hline Spacing linear & & 0.08 & & 0.49 & \\
\hline Spacing quadratic & & 0.91 & & 0.82 & \\
\hline
\end{tabular}


top-log chips $(p \geq 0.49)$. However, thinning was associated with $1 \%$ to $5 \%$ lower slab-wood chip basic densities, relative to the unthinned controls $(p=0.06)$, and slab-wood chip density tended to decrease linearly, as PCT intensity increased $(p=0.08)$. Duchesne et al. (2013) reported a much stronger trend between basic wood density at stump height and PCT spacing $(p<0.01)$. These trends in basic density translated into similar trends in chip bulk density (the mass of a given volume of packed chips), which directly affects the productivity of both kraft and mechanical pulping processes (Hussein et al. 2006).

\section{Pulping behaviour}

There were differences in the kraft pulping behaviour between chips from the two types of wood (Table 3 ). Top-log chips were no more difficult to pulp to a 30 kappa than the corresponding slab-wood chips, as evidenced by the similar $\mathrm{H}$-factors $(p=0.66)$. However, top-log chips had lower pulp yields $(p<$ $0.01)$, and consumed more EA $(p<0.01)$ than slab-wood chips, during kraft pulping. Furthermore, kraft pulp fibres from slabwood chips tended to be $8 \%$ longer $(p<0.01)$ and $10 \%$ coarser $(p<0.01)$ than the corresponding top-log kraft pulps. These fibre property trends are consistent with earlier kraft pulping studies, which compared juvenile and mature woods for balsam fir specifically (Drost et al. 2003) and other softwoods (Hatton 1997), and reported that the quality of top-logs is very similar to that of juvenile wood. With TMP pulping, slab-wood chips required $8 \%$ more energy than the top-log chips to produce pulps of $100 \mathrm{~mL}$ freeness $(p=0.02)$. Slab-wood TMP pulps also tended to have $8 \%$ to $13 \%$ longer fibres $(p<0.01)$, with lower levels of fines, than the corresponding top-log TMP pulps $(p=0.01)$.

\section{Pulp behaviour and properties, as influenced by PCT}

Top-log pulp properties, both for kraft (Table 4) and TMP pulping (Table 5), were largely unaffected by PCT $(p \geq 0.14)$. PCT treatment had a greater influence on pulps made from slabwood chips. Differences in the $\mathrm{H}$-factor required to pulp to a 30 kappa residual lignin target were minor between chips from the unthinned control and the 4-ft spacing, but there was a strong linear trend in $\mathrm{H}$-factor when going from 4- $\mathrm{ft}$ to 8 - $\mathrm{ft}$ spacing

Table 3. Pairwise comparisons of the pulping properties of slab-wood and top-log chips a) kraft pulped to 30 kappa and b) TMP refined to a Canadian Standard Freeness of $100 \mathrm{mLs}$. "Pairwise" refers to comparisons between slab-wood and top-log pulping and pulp properties for each PCT/block combination.

\begin{tabular}{lccc}
\hline & $\begin{array}{c}\text { Slab-wood } \\
\text { chips }\end{array}$ & $\begin{array}{c}\text { Top-log } \\
\text { chips }\end{array}$ & $\begin{array}{c}\text { Paired } \boldsymbol{t} \text {-test } \\
\boldsymbol{p}>\boldsymbol{t}\end{array}$ \\
\hline a) Kraft Pulping and Pulp Properties & & & \\
H-factor to 30 Kappa & 1813 & 1820 & 0.66 \\
Screened Kraft Pulp Yield (\%) & 46.9 & 46.0 & $<0.01$ \\
\% EA consumed & 10.6 & 10.8 & $<0.01$ \\
Length weighted fibre length (mm) & 2.47 & 2.29 & $<0.01$ \\
Pulp Coarseness ( $\mu$ g/m) & 131 & 119 & $<0.01$ \\
& & & \\
b) TMP Refining and Pulp Properties & 10.6 & 9.8 & 0.02 \\
Specific refining energy (MJ/kg) & 1.37 & 1.24 & $<0.01$ \\
Length weighted fibre length (mm) & 58.6 & 54.9 & $<0.01$ \\
R-48 Long Fibre fraction (\%) & 23.5 & 24.4 & 0.01 \\
P-200 Fines Fraction (\%) & & & \\
\hline
\end{tabular}

( $p=0.01$; Table 4). The H-factors required to reach the kappa target increased by $6 \%$ over this range. Screened kraft pulp yields decreased by $2 \%$ between the 6 - $\mathrm{ft}$ and 8 - $\mathrm{ft}$ spacing $(p=0.02)$. The coarseness of slab-wood kraft pulps decreased by up to $9 \%$, in proportion to increasing thinning intensity $(p=0.03)$. These pulp yield and coarseness results are consistent with those reported by Hussein et al. (2006); however, the magnitude of the effects reported by these authors was almost twice that noted here, possibly due to site or other factors.

With respect to TMP, PCT had little or no effect on the specific refining energy (SRE) required to reach a target freeness of $100 \mathrm{~mL}$ for either the top-log or slab-wood chips $(p \geq 0.13$, Table 5). The only effect of PCT on TMP quality noted was a linear trend on the fibre length of slab-wood TMP pulps, which decreased by $4 \%$ as PCT intensity increased $(p=0.02)$.

\section{Pulping productivity}

In general for kraft pulping, top-log chips had lower yields, and produced pulps with shorter, finer fibres than the corresponding slab-wood chips (Table 3), across all PCT treatment levels (Table 4). The main effects of PCT on pulping occurred with slab-wood chips and not top-log chips. The magnitude of these effects, when considered individually, may not seem great; however, when considered cumulatively, the variability in productivity and yields from chips from thinned stands could result in $9 \%$ less kraft being produced per day, which could cost a typical industrial scale kraft mill as much as $\$ 19000000$ per year in lost production if these chips were the mill's only fibre source. For PCT to be of value to the pulping sector, these losses must be mitigated without compromising pulp quality. With TMP refining, top-log chips required less energy to reach the freeness target, but also produced pulps with shorter fibres than the slabwood pulps (Tables 3 and 5). For TMP refining, the effects of thinning are primarily on pulp quality, which may be negatively affected by the shorter-fibred pulps generated when pulping slab-wood from heavily thinned stands.

The variability between slab-wood and top-log pulping and pulp properties can be large enough to mask the effects of PCT on wood properties, pulping and pulp quality. Furthermore, PCT affects the proportion of merchantable timber available from a stand (Pitt et al. 2013c). This alters the proportion of top-log chips generated from a given PCT treatment. For the Green River study, about $8 \%$ of the volume of trees from the unthinned controls and the 4 - $\mathrm{ft}$ spacing would be generated from top logs, while less than $5 \%$ of the volume of trees from the $6-\mathrm{ft}$ and 8 - $\mathrm{ft}$ spacings would be generated from top-log chips (Duchesne et al. 2013). The proportion of sawlog volume recovered as chips was relatively constant across the PCT treatments and ranged between $50.7 \%$ and $49.7 \%$ (Duchesne et al. 2013). This effect can mask some aspects of the effects of PCT, especially in a study such as this one, where a mass of chips, not individual stems, are being analyzed. This potential source of error was minimized by analyzing and reporting the effects of PCT treatments separately for top-log and slabwood chips in subsequent sections of this report. The average chip properties can be determined by weighted averages based on the proportion of the two chip types. Also, the benefits of chip segregation may also be evaluated. 
Table 4. The effect of PCT on selected kraft pulp production and pulp quality properties for Kappa 30 pulps. Least squares means for the different treatments and the $p$-values for contrasts comparing thinned vs. unthinned, and linear and quadratic effects of spacings for pulps made from either top-log or slab-wood chips, as well as the effect of spacing's on the differences between slab-wood and top-log pulps.

\begin{tabular}{|c|c|c|c|c|c|c|c|c|c|}
\hline Property & Wood type & Unthinned & $4 \mathrm{ft}$ & $6 \mathrm{ft}$ & $8 \mathrm{ft}$ & S.E. & $\begin{array}{l}\text { Unthinned vs. } \\
\text { thinned } \\
\qquad(p>F)\end{array}$ & $\begin{array}{l}\text { Spacing - } \\
\text { linear } \\
(p>F)\end{array}$ & $\begin{array}{l}\text { Spacing - } \\
\text { quadratic } \\
\quad(p>F)\end{array}$ \\
\hline & \multicolumn{9}{|c|}{ Pulp Production } \\
\hline \multirow{3}{*}{$\begin{array}{l}\text { H-factor to } 30 \\
\text { kappa }\end{array}$} & Top & 1808 & 1829 & 1811 & 1832 & 31 & 0.66 & 0.69 & 0.99 \\
\hline & Slab & 1790 & 1760 & 1823 & 1878 & 23 & 0.29 & 0.01 & 0.10 \\
\hline & Difference & 18 & 69 & -12 & -44 & 24 & 0.64 & 0.04 & 0.12 \\
\hline \multirow{3}{*}{$\begin{array}{l}\text { Screened pulp } \\
\text { yield } \\
(\%)\end{array}$} & Top & 45.9 & 46.3 & 45.6 & 46.1 & 0.4 & 0.74 & 0.97 & 0.97 \\
\hline & Slab & 46.7 & 47.2 & 47.3 & 46.3 & 0.3 & 0.47 & 0.36 & 0.02 \\
\hline & Difference & -0.84 & -0.92 & -1.63 & -0.25 & 0.4 & 0.85 & 0.54 & 0.09 \\
\hline \multirow{4}{*}{$\begin{array}{l}\text { EA consumed } \\
(\%)\end{array}$} & Top & 10.8 & 10.8 & 10.7 & 10.8 & 0.04 & 0.99 & 0.76 & 0.79 \\
\hline & Slab & 10.6 & 10.6 & 10.6 & 10.7 & 0.01 & 0.37 & 0.02 & 0.08 \\
\hline & Difference & 0.2 & 0.2 & 0.1 & 0.1 & 0.1 & 0.81 & 0.33 & 0.80 \\
\hline & \multicolumn{9}{|c|}{ Pulp Quality } \\
\hline \multirow{3}{*}{$\begin{array}{l}\text { Length-weighted } \\
\text { fibre length } \\
(\mathrm{mm})\end{array}$} & Top & 2.34 & 2.28 & 2.22 & 2.33 & 0.06 & 0.36 & 0.69 & 0.19 \\
\hline & Slab & 2.46 & 2.60 & 2.48 & 2.38 & 0.07 & 0.90 & 0.13 & 0.06 \\
\hline & Difference & -0.12 & -0.32 & -0.26 & -0.05 & 0.08 & 0.43 & 0.27 & 0.02 \\
\hline \multirow{3}{*}{$\begin{array}{l}\text { Pulp coarseness } \\
(\mu \mathrm{g} / \mathrm{m})\end{array}$} & Top & 0.117 & 0.119 & 0.118 & 0.122 & 0.002 & 0.31 & 0.19 & 0.69 \\
\hline & Slab & 0.133 & 0.137 & 0.130 & 0.125 & 0.003 & 0.45 & 0.03 & 0.14 \\
\hline & Difference & -0.016 & -0.018 & -0.012 & -0.003 & 0.003 & 0.18 & 0.01 & 0.12 \\
\hline \multirow{3}{*}{$\begin{array}{l}\text { Apparent sheet } \\
\text { density } \\
(\mathrm{kg} / \mathrm{m})^{3}\end{array}$} & Top & 734 & 751 & 756 & 771 & 5.9 & $<0.01$ & $<0.01$ & 0.89 \\
\hline & Slab & 755 & 750 & 760 & 773 & 5.8 & 0.41 & 0.04 & 0.16 \\
\hline & Difference & -21 & 1 & -4 & -2 & 9 & 0.11 & 0.24 & 0.29 \\
\hline \multirow{3}{*}{$\begin{array}{l}\text { Sheet surface } \\
\text { roughness } \\
(\mathrm{mL} / \mathrm{min})\end{array}$} & Top & 40.7 & 37.7 & 39.9 & 37.5 & 1.8 & 0.30 & 0.39 & 0.87 \\
\hline & Slab & 56.6 & 66.4 & 58.5 & 48.6 & 5.2 & 0.99 & 0.16 & 0.17 \\
\hline & Difference & -15.9 & -28.7 & -14.6 & -11.3 & 5.5 & 0.73 & 0.28 & 0.18 \\
\hline \multirow{3}{*}{$\begin{array}{l}\text { Air resistance } \\
\text { (porosity) } \\
(\mathrm{sec} / 100 \mathrm{~mL})\end{array}$} & Top & 425 & 422 & 490 & 461 & 34 & 0.42 & 0.27 & 0.71 \\
\hline & Slab & 402 & 471 & 447 & 544 & 40 & 0.10 & 0.06 & 0.73 \\
\hline & Difference & 23 & -49 & 43 & -83 & 61 & 0.48 & 0.43 & 0.67 \\
\hline \multirow{3}{*}{$\begin{array}{l}\text { Zero-span tensile } \\
\text { breaking length } \\
(\mathrm{km})\end{array}$} & Top & 15.7 & 15.9 & 16.0 & 15.9 & 0.21 & 0.42 & 0.57 & 0.48 \\
\hline & Slab & 18.6 & 18.7 & 18.3 & 18.0 & 0.4 & 0.60 & 0.24 & 0.52 \\
\hline & Difference & -2.9 & -2.8 & -2.4 & -2.1 & 0.5 & 0.45 & 0.25 & 0.83 \\
\hline \multirow{3}{*}{$\begin{array}{l}\text { Burst index } \\
\left(\mathrm{kPa} \cdot \mathrm{m}^{2} / \mathrm{g}\right)\end{array}$} & Top & 12.6 & 13.2 & 12.8 & 12.9 & 0.30 & 0.36 & 0.75 & 0.42 \\
\hline & Slab & 11.8 & 12.0 & 11.8 & 11.7 & 0.2 & 0.89 & 0.51 & 0.40 \\
\hline & Difference & 0.8 & 1.1 & 1.1 & 1.2 & 0.4 & 0.47 & 0.52 & 0.83 \\
\hline \multirow{3}{*}{$\begin{array}{l}\text { Tensile index } \\
\text { (N.m/g) }\end{array}$} & Top & 136 & 143 & 138 & 140 & 2.9 & 0.40 & 0.84 & 0.50 \\
\hline & Slab & 129 & 131 & 135 & 133 & 2.0 & 0.10 & 0.09 & 0.37 \\
\hline & Difference & 9.0 & 12.3 & 3.9 & 6.9 & 3.2 & 0.74 & 0.33 & 0.96 \\
\hline \multirow{3}{*}{$\begin{array}{l}\text { Tear Index } \\
\left(\mathrm{mN} \cdot \mathrm{m}^{2} / \mathrm{g}\right)\end{array}$} & Top & 10.4 & 10.4 & 9.8 & 10.3 & 0.3 & 0.39 & 0.46 & 0.40 \\
\hline & Slab & 12.0 & 12.3 & 11.9 & 11.6 & 0.3 & 0.77 & 0.27 & 0.42 \\
\hline & Difference & -1.6 & -1.8 & -2.1 & -1.3 & 0.4 & 0.81 & 0.74 & 0.29 \\
\hline
\end{tabular}

Kraft pulping and pulp quality

Typical plots that relate $\mathrm{H}$-factor to kappa target are presented in Fig. 1a for both slab-wood and top-log wood from the unthinned stands. Chips from the different thinning treatments showed the same trend, suggesting that kraft pulping was consistent and differed only in rates and yields. The latter are more readily assessed by plotting kappa against pulp yields (Fig. $1 \mathrm{~b}$ ) and by comparing $\mathrm{H}$-factors required to reach a 30 kappa target (Table 4 ).

Kraft pulping kinetics of the slab-wood and top-logs from the unthinned stands of all three blocks are presented in Fig. 1b. All top-log chips kraft pulped in a similar manner, 
Table 5. The effect of PCT on selected Thermomechanical pulp production and pulp quality properties for TMP pulps at $100 \mathrm{~mL}$ of freeness. Least squares means for the different treatments and the $p$-values for contrasts comparing thinned vs. unthinned, and linear and quadratic effects of spacings for pulps made from either top-log or slab-wood chips, as well as the effect of spacing's on the differences between slab-wood and top-log pulps.

\begin{tabular}{|c|c|c|c|c|c|c|c|c|c|}
\hline Property & Wood type & Unthinned & $4 \mathrm{ft}$ & $6 \mathrm{ft}$ & $8 \mathrm{ft}$ & S.E. & $\begin{array}{l}\text { Unthinned } \\
\text { vs. thinned } \\
\quad(p>F)\end{array}$ & $\begin{array}{l}\text { Spacing - } \\
\text { linear } \\
(p>F)\end{array}$ & $\begin{array}{l}\text { Spacing - } \\
\text { quadratic } \\
\qquad(p>F)\end{array}$ \\
\hline \multirow{3}{*}{$\begin{array}{l}\text { Specific } \\
\text { refining } \\
\text { energy } \\
(\mathrm{MJ} / \mathrm{kg})\end{array}$} & Top & 9.7 & 9.7 & 9.9 & 10.1 & 0.30 & 0.53 & 0.34 & 0.89 \\
\hline & Slab & 11.0 & 10.3 & 10.3 & 10.8 & 0.35 & 0.26 & 0.77 & 0.13 \\
\hline & Difference & -1.3 & -0.6 & -0.4 & -0.8 & 0.58 & 0.31 & 0.49 & 0.37 \\
\hline \multirow{3}{*}{$\begin{array}{l}\text { Length } \\
\text { weighted fibre } \\
\text { length }(\mathrm{mm})\end{array}$} & Top & 1.23 & 1.22 & 1.24 & 1.24 & 0.03 & 0.91 & 0.74 & 0.71 \\
\hline & Slab & 1.41 & 1.37 & 1.36 & 1.35 & 0.01 & 0.01 & 0.02 & 0.26 \\
\hline & Difference & -0.17 & -0.15 & -0.12 & -0.11 & 0.03 & 0.21 & 0.13 & 0.83 \\
\hline \multirow{3}{*}{$\begin{array}{l}\mathrm{R}-48 \text { long fibre } \\
\text { fraction }(\%)\end{array}$} & Top & 55.0 & 55.0 & 54.7 & 54.7 & 0.4 & 0.75 & 0.59 & 0.94 \\
\hline & Slab & 58.8 & 58.4 & 59.0 & 58.1 & 0.4 & 0.54 & 0.53 & 0.60 \\
\hline & Difference & -3.8 & -3.5 & -4.2 & -3.4 & 0.7 & 0.85 & 0.88 & 0.78 \\
\hline \multirow{3}{*}{$\begin{array}{l}\text { P-200 fines } \\
\text { fraction }(\%)\end{array}$} & Top & 24.6 & 24.1 & 24.6 & 24.3 & 0.6 & 0.77 & 0.96 & 0.86 \\
\hline & Slab & 24.1 & 23.2 & 22.9 & 23.8 & 0.4 & 0.12 & 0.54 & 0.05 \\
\hline & Difference & 0.5 & 0.9 & 1.7 & 0.6 & 0.7 & 0.50 & 0.75 & 0.28 \\
\hline \multirow{3}{*}{$\begin{array}{l}\text { Apparent } \\
\text { sheet density } \\
(\mathrm{kg} / \mathrm{m})^{3}\end{array}$} & Top & 317 & 317 & 313 & 313 & 5 & 0.73 & 0.55 & 0.95 \\
\hline & Slab & 354 & 353 & 341 & 359 & 8 & 0.47 & 0.79 & 0.88 \\
\hline & Difference & -37 & -36 & -28 & -46 & 10 & 0.97 & 0.69 & 0.36 \\
\hline \multirow{3}{*}{$\begin{array}{l}\text { Sheet surface } \\
\text { roughness } \\
(\mathrm{ml} / \mathrm{min})\end{array}$} & Top & 248 & 244 & 239 & 243 & 5 & 0.34 & 0.42 & 0.45 \\
\hline & Slab & 210 & 214 & 221 & 213 & 10 & 0.64 & 0.73 & 0.60 \\
\hline & Difference & 38 & 30 & 17 & 30 & 11 & 0.36 & 0.47 & 0.39 \\
\hline \multirow{3}{*}{$\begin{array}{l}\text { Tensile index } \\
\text { (N.m/g) }\end{array}$} & Top & 38.1 & 38.7 & 39.1 & 38.7 & 0.8 & 0.40 & 0.52 & 0.50 \\
\hline & Slab & 41.2 & 41.1 & 40.9 & 41.7 & 0.8 & 0.97 & 0.71 & 0.56 \\
\hline & Difference & -3.1 & -2.3 & -1.7 & -3.0 & 1.3 & 0.63 & 0.87 & 0.47 \\
\hline \multirow{3}{*}{$\begin{array}{l}\text { Tear index } \\
\left(\mathrm{mN} \cdot \mathrm{m}^{2} / \mathrm{g}\right)\end{array}$} & Top & 6.6 & 6.7 & 6.7 & 6.7 & 0.1 & 0.62 & 0.55 & 0.91 \\
\hline & Slab & 7.8 & 7.8 & 7.7 & 7.8 & 0.1 & 0.63 & 0.90 & 0.41 \\
\hline & Difference & -1.1 & -1.1 & -1.2 & -1.0 & 0.1 & 0.80 & 0.94 & 0.70 \\
\hline \multirow{3}{*}{$\begin{array}{l}\text { Scattering } \\
\text { coefficient } \\
\left(\mathrm{m}^{2} / \mathrm{kg}\right)\end{array}$} & Top & 681 & 683 & 674 & 665 & 8 & 0.46 & 0.14 & 0.51 \\
\hline & Slab & 639 & 656 & 651 & 649 & 5 & 0.06 & 0.27 & 0.12 \\
\hline & Difference & 42 & 27 & 24 & 16 & 10 & 0.11 & 0.09 & 0.73 \\
\hline
\end{tabular}

regardless of where they were harvested. The two slab-wood chip samples from the Upper Belone sites also pulped in a similar manner to each other, but differently than slab-wood chips from the Summit Road site, reflecting differences between sites, possibly associated with tree age (Pitt et al. 2013c). Screened kraft pulp yields for the top-log chips were approximately $1.5 \%$ lower than those of the corresponding slab-wood chips. These observations are consistent with those of Hatton (1997) for other softwoods. However, the two Upper Belone slab-wood samples pulped more like the top-log chips at higher kappa numbers (40 and above), which could reflect a site effect on slab-wood quality, a sawmilling effect, or be due to the higher levels of rejects found with the top-log pulps.
Thinning had no effect on kraft pulping ( $\mathrm{H}$-factor to kappa, screened pulp yield, and EA consumption) of toplog chips $(p \geq 0.69$; Table 4$)$ but did affect that of slab-wood chips (Table $4 ; p \leq 0.02$ ). Linear trends suggest that slabwood chips from thinned stands required up to a $5 \%$ higher $\mathrm{H}$-factor to reach the target kappa $(p=0.01)$, while effects on EA consumption were minimal (although statistically significant). The screened pulp yields of these chips tended to increase with thinning by $0.6 \%$ at the $6-\mathrm{ft}$ spacing, but dropped to unthinned levels with wider thinning spacing ( $p=0.02$, quadratic effect). Other researchers have found similar effects of thinning on kraft pulp yield, but have indicated that this was due to higher levels of compression 
a) Kappa number (residual lignin)

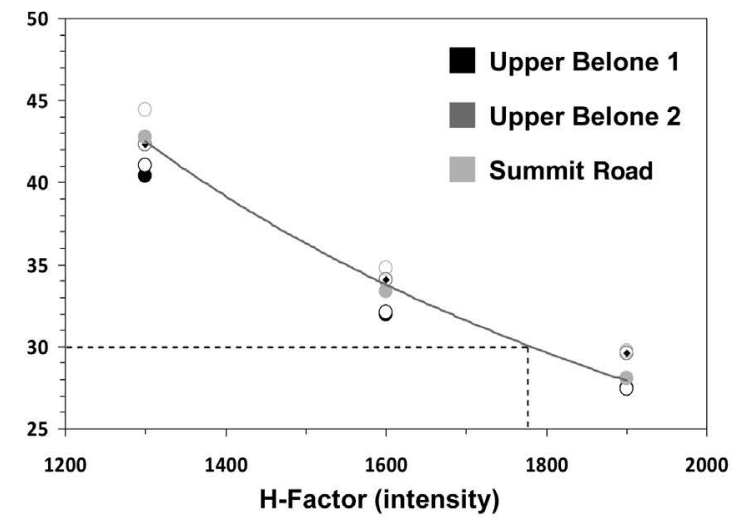

b) Screened pulp yield (\%)

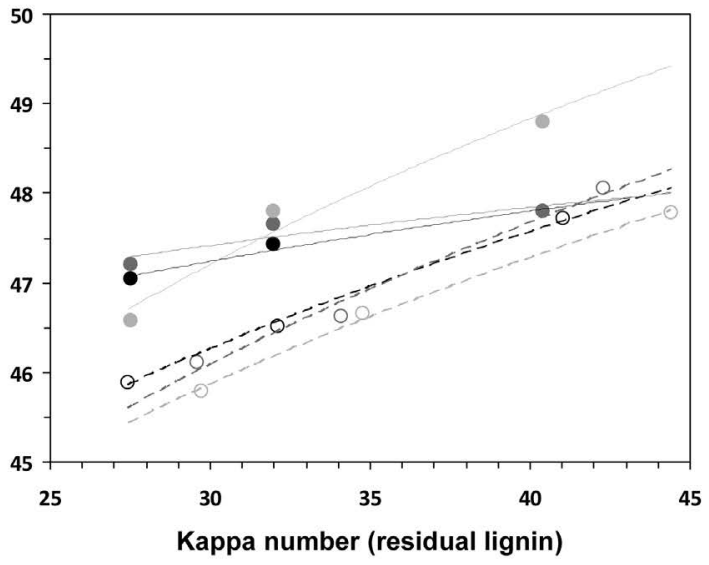

Fig. 1. Kraft pulping kinetics (a) and productivity (b) for chips from unthinned stands. Chips from top-wood (open circles) and slab-wood (solid circles) are identified for each of the three blocks harvested. In (a), the solid line demonstrates the kinetics of pulping slab-wood from the Summit Road site; dashed lines reflect the $\mathrm{H}$-factor required to reach Kappa 30 . In (b), trend lines indicate the rate of pulping (dashed for top-wood; solid for slab-wood).

wood in chips from thinned stands (Hussein et al. 2006). It is possible that these effects could be due to differences in the proportion of top-log chips in the overall chip supply, or to other factors, such as site quality and/or tree age.

As observed with kraft pulping, the fibre lengths and coarsenesses of top-log kraft pulps were largely unaffected by thinning $(p \geq 0.19)$. Apparent handsheet density did show a strong linear trend with thinning intensity and a $5 \%$ increase in sheet density across the unthinned control to 8 - $\mathrm{ft}$ spacings $(p<0.01)$ was noted. This would suggest changes in fundamental fibre dimensions that could affect collapsibility. Similar trends were noted by Hussein et al. (2006). However, this increase in sheet density was not large enough to affect other handsheet properties of top-log kraft pulps, which were unaffected by thinning $(p \geq 0.27)$.

The effects of thinning on slab-wood kraft pulp quality were more evident. There was a 5\% drop in fibre length with thinning intensity; however, this was regained at the 8 - $\mathrm{ft}$ spacing (quadratic effect; $p=0.06$; Table 4). There was a $6 \%$ decrease in coarseness that correlated with thinning intensity (linear effect; $p=0.03$ ). Once again, these results are consistent with those reported by Hussein et al. (2006), except that they noted no rebound in fibre length. Our observed effects on fibre length and coarseness were not large enough to have major effects on handsheet properties $(p \geq 0.16)$. Only air resistance, an indicator of air porosity through a sheet, seemed to be affected by thinning $(p=0.06)$. Results show that porosity decreased by over $25 \%$ (as measured by the time required to let $100 \mathrm{~mL}$ of air flow through a sheet). Tensile index, an in-plane measurement of sheet strength, tended to be greater for all pulps from thinned stands, relative to those from unthinned controls $(p=0.10)$. Other handsheet strength properties, such as zero span tensile breaking length, burst index, and tear index, showed no trend with PCT intensity $(p \geq 0.36)$, suggesting that pulps produced from thinned stands were of similar quality to pulps produced form unthinned stands.

The overall impact of thinning on kraft pulp quality was relatively minor, and most of this variation was noted in slab-wood pulp quality. Differences in the quality of pulps from the top-log and slab-wood chips were only correlated with thinning when slab-wood pulp quality was affected (Table 4), which is consistent with the observation that pulp quality from top-log chips was poorly correlated with thinning. Differences in porosity that did correlate with thinning could be viewed as an opportunity for the use of these pulps in special applications. Regardless, the key handsheet strength properties appear to be unaffected by PCT. While no major negative impacts of thinning on key kraft pulp properties such as strength attributes were noted, neither were there any improvements in pulp quality. While the effects of PCT on kraft pulp quality are minor, the cumulative effect of thinning on basic wood density, $\mathrm{H}$-factor and pulp yield could reduce productivity for a typical kraft mill by $5 \%$ to $7 \%$ per annum if the mill is running solely on fibre from thinned stands. This is shown in Fig. 2 and is expressed as the amount of pulp produced from $1 \mathrm{~m}^{3}$ of digester (filled with chips). The cost of this to a typical 1000 tpd kraft mill, operating 350 days a year, would range between $\$ 13$ million and \$19 million per annum in pulp not produced (at current prices of $\$ 780$ per tonne of

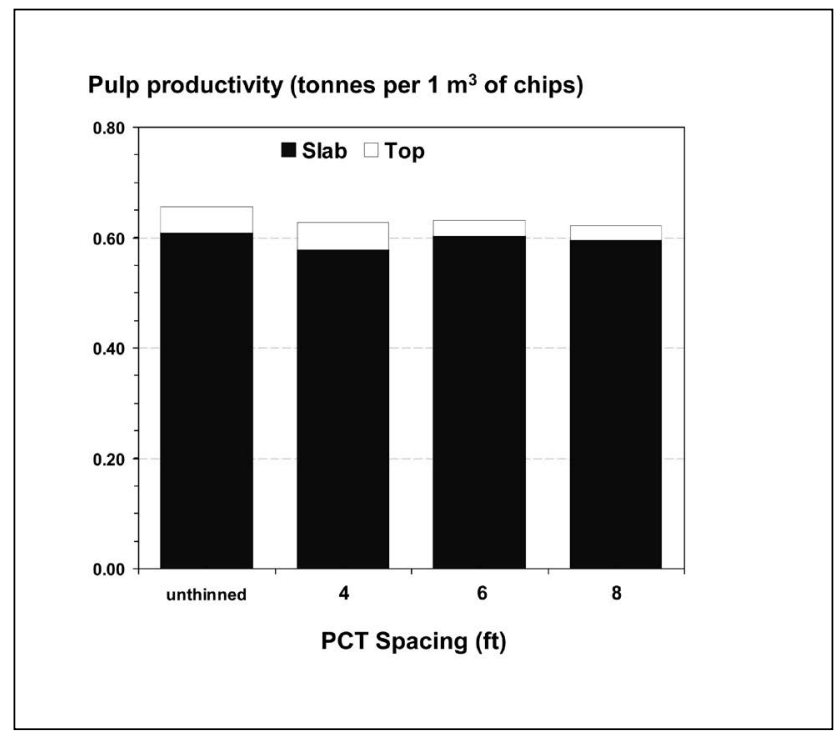

Fig. 2. Kraft pulp productivity [tonnes of pulp produced from 1 $\mathrm{m}^{3}$ of chips (slab-wood or top-wood)], estimated from the samples drawn from the thinned and unthinned stands. 
pulp). If top-log chips could be removed from the chip furnish, these losses would be cut by over three quarters for the 6-ft and 8 -ft spacings.

\section{Thermomechanical (TMP) pulping and pulp quality}

The specific refining energy (SRE-the electrical energy required to make 1 tonne of TMP pulp at $100 \mathrm{~mL}$ of CSF) for chips from top-logs or slab-wood ranged between $9.5 \mathrm{MJ} / \mathrm{kg}$ and $10.9 \mathrm{MJ} / \mathrm{kg}$, with slab-wood chips requiring $4 \%$ to $12 \%$ more refining energy to achieve the freeness target than the corresponding top-log chips (Fig.3). Thinning had no effects on SRE of slab-wood chips or top-log chips (slab-wood, $p=0.26$; top-log, $p=0.53$; Table 5).

The effects of thinning on TMP pulp quality for both types of wood were even less evident than with the kraft pulps. Mechanical pulps made from top-log chips were not affected by thinning $\left(p^{3} \geq 0.34\right)$. The only effect of thinning on TMP slabwood pulps was on fibre length $(p=0.01)$; there was a linear decrease in fibre length with thinning intensity $(p=0.02)$. However, the drop in fibre length was less than 5\%, which was not large enough to adversely affect tensile index $(p=0.40)$ or tear index $(p=0.55)$. The only other TMP pulp property affected was the scattering coefficient, which was approximately $2 \%$ lower for slab-wood pulps from the unthinned stands, relative to those from any of the thinning treatments $(p=0.06)$. Again, this difference was considered trivial. As with the kraft pulps, no beneficial effects, nor any major negative impacts, on TMP refining or pulp quality were attributed to thinning.

The effects of thinning on TMP pulp quality were minor, but the impacts of thinning on productivity warrant closer inspection. In this instance, it is preferable to examine the SRE required to produce 1 tonne of paper grade thermomechanical pulp. For extrapolation to the mill level, the SRE is expressed as $\mathrm{kWh}$ needed to refine 1 tonne of chips into pulp (NB 10MJ = to $2.778 \mathrm{kWh}$ ). For a TMP mill refining slab-wood chips from

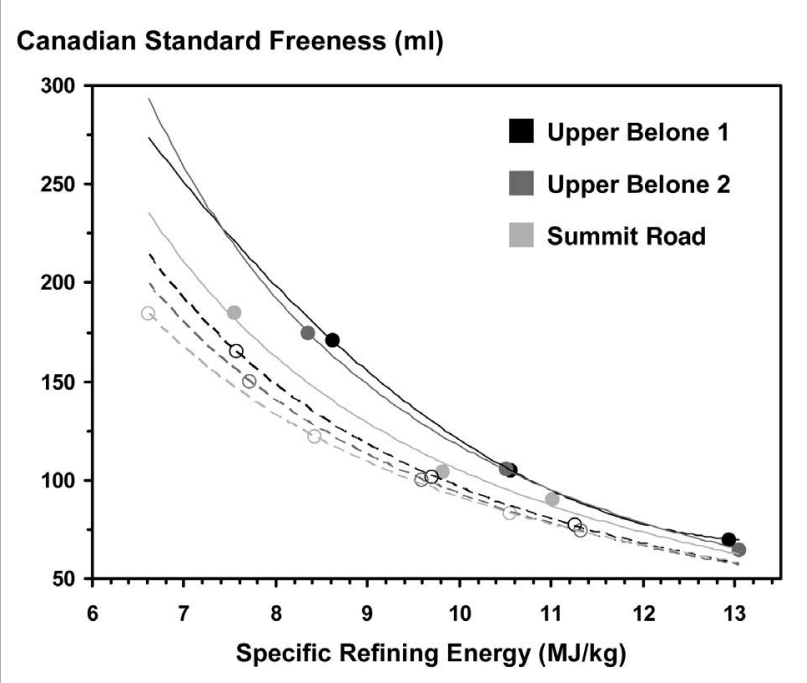

Fig. 3. Specific refining energy required to produce one tonne of thermomechanical pulp of $100 \mathrm{~mL}$ freeness from chips from unthinned stands. Chips from top-wood (open circles) and slab-wood (solid circles) are identified for each of the three blocks harvested. Trend lines suggest the nature of the refining curve (dashed for top-wood; solid for slab-wood). different PCT treatments, we note that the 4-ft and 6-ft spacing require $7 \%$ and $5 \%$ less energy, respectively, than chips from the unthinned control. The savings in electrical energy to a $750 \mathrm{tpd}$ mill using only chips from these stands would be on the order of $\$ 2$ million to $\$ 4$ million per annum.

\section{Influences on production costs}

This study has shown that while the effects of PCT on both the kraft and thermomechanical (TMP) pulp quality were minor, effects on productivity could be significant. For kraft mills, the loss in productivity related to the cumulative effects of lower wood densities, lower pulp yields, and higher pulping times (H-factors) associated with PCT could be costly but could be alleviated somewhat by the optimization of pulping conditions for the specific furnish being used. This would entail optimizing for chemical charge, pulping temperature profiles, and chip size distributions. For a TMP mill, the benefits of thinning are realized as a reduction in electrical energy requirements. From a pulping perspective, these potential losses or gains need to be considered in the context of the incremental chip supply that can arise from PCT.

Because of the additional merchantable wood volume that arises from PCT (Pitt et al. 2103b), there is an increase in lumber and chip volumes that can be obtained from a hectare of forest (Duchesne et al. 2013). For chips, the volumes are converted to mass of chips per hectare by applying the appropriate wood density (Table 2). Based on data from the six Green River replicates collected over time, the mass of chips expected from a PCT thinning regime, as a function of the stand age (Fig. 4a), suggests that a maximum chip mass, on a per-hectare basis, is expected from stands between 45 and 55 years after overstory removal, depending on thinning intensity. These data also show that the nominal 6- $\mathrm{ft}$ spacing produced a $13 \%$ increase in chips, on a mass-per-hectare basis, over that of the unthinned stands. This was the largest increase in chip mass of any of the PCT spacing and coincides with the increase in lumber from the nominal 6-ft spacing treatment, which also provided the best value for the lumber sector (Duchesne et al. 2013).

As well as an increase in chip mass from the different PCT treatments, the proportion of top-log and sawmill residual chips was also estimated for the full Green River data set (Fig. 4b). In actuality, these two chip types would likely be purchased and pulped as a mixture; with no premium or penalty paid for having more of one type of chip over another. However, it is recognized that the make-up of a mill's chip furnish has an impact on pulping and pulp quality. Furthermore, uniformity in chip furnish is also highly desirable for a pulp mill. The effects of pulping chip mixtures on pulping and pulp quality could only be fully assessed by pulping specific chip mixtures, which is beyond the scope of this paper. Therefore, for the purposes of this study, estimates of a specific property for a pulp produced from chip mixtures are calculated as averages weighted by the proportion of top-log or sawmill residual chips in the furnish. But it is recognized that opportunities exist for optimization of both kraft and thermomechanical pulping. With that in mind, it is evident that the proportion of top-log chips decreases with the extent of thinning, with the 8 - $\mathrm{ft}$ spacing PCT giving the highest levels of slab-wood in the chip furnish. Again, it is clear that stand age also has a significant effect, with stands at 45 to 55 years after overstory removal expected to have the lowest levels of top-log chips, and therefore, the highest levels of slabwood chips. Kraft pulps made from furnishes rich in sawmill 
a) Chips produced (tonnes/ha)

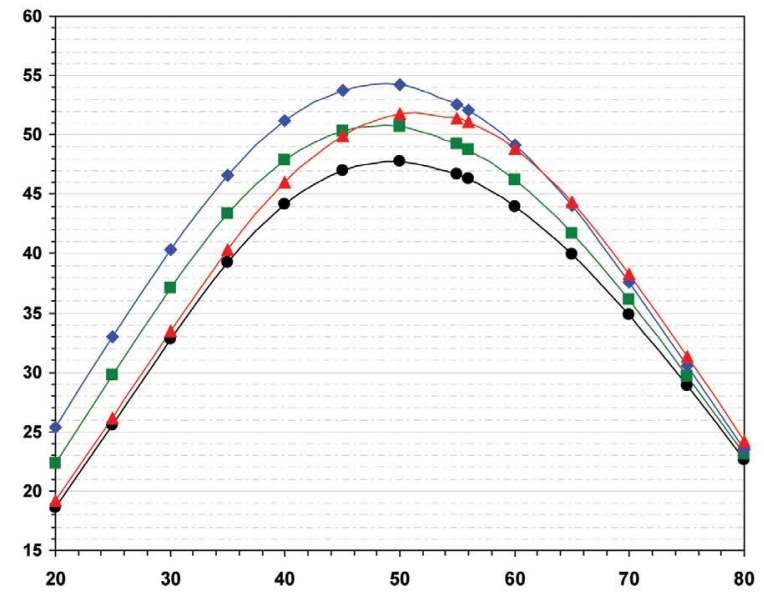

b) Top-log chips as a percentage of total chip mass

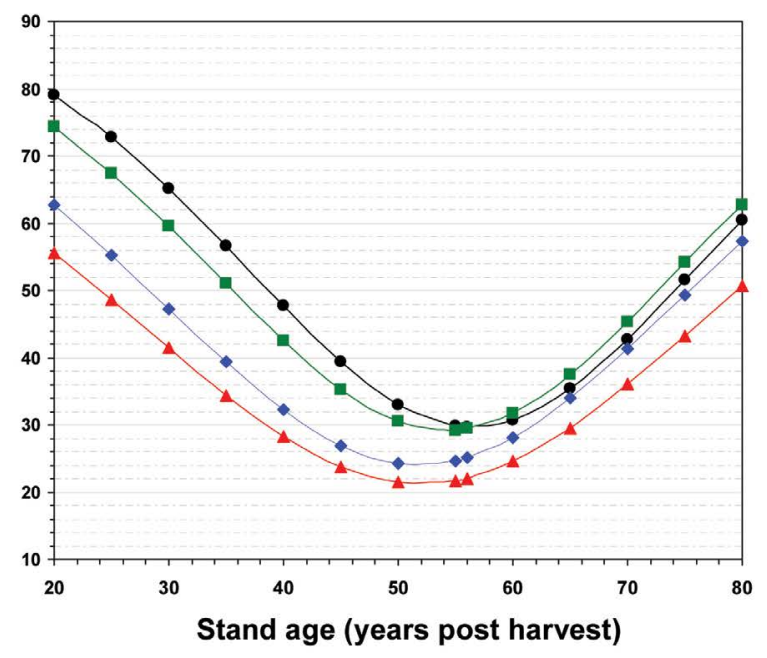

Margin was estimated for both bleached kraft pulp and newsprint by estimating the cost of production, summing these costs and subtracting them from sales revenue. Margins were standardized by the chips expected per hectare and production costs were estimated using the data generated during this study or from literature sources. Pricing, costs, and other assumptions are provided in Table 6. A more detailed, holistic approach, encompassing the entire value chain from harvest to end products for lumber and pulp, is presented in a follow-up paper (Pitt et al. 2013a). In this follow-up paper, a model is presented where parameters can be modified so that users can adjust costs and market inputs for scenario planning and sensitivity analyses.

The margin generated from the estimated northern bleached softwood kraft pulp (NBSK) produced from the chip furnishes described in Fig. 4a and Fig. $4 \mathrm{~b}$, and applying the factors described in Table 6, is presented in Fig. 5a. Similar margin estimates are presented for the production of newsprint from a TMP mill using the chip furnishes described (Fig. 5b). Comparison of the margins per hectare between the two different products suggests that kraft pulps are much more profitable than newsprint. This reflects the state of the markets for these two products and does not reflect the effects of PCT on profitability. Therefore, no further comparisons between the two products are warranted in this context. The effects of PCT on the margin per hectare within either the NBSK or newsprint scenarios are presented to encompass the two most likely scenarios in eastern Canada.

For the NBSK scenario, the greatest margins are seen in the 45- to 55-year residual chips would be coarser, have longer fibres and slightly higher pulp yields (based on Table 3) than chip furnishes with higher top-log chip contents. Likewise, TMP pulps made from furnishes rich in sawmill residual chips would require more energy to refine to a target freeness and have higher levels of long fibres (based on Table 3).

In this study, two scenarios were used to assess economic impact margin attributed to the bleached kraft pulp (NBSK) or newsprint made from TMP pulp that could be produced from chip furnishes generated by lumber production from the trees that were harvested from a hectare of land. Margin, in this case, is defined as the difference between selling price of the product(s) and the sum of all production and fibre costs, expressed on a per-hectare-of-harvested area basis. In this context, margin can either be positive (profit) or negative (loss) (Table 6), with consideration being given to the proportion of sawmill residual chips and top-log chips (Fig. 4b). We assumed that newsprint and NBSK quality are acceptable for commodity markets, with no quality penalties applied to selling prices. stand age window, reflecting the maximum chip mass generated per hectare, as well as the higher levels of slab-wood chips, which tend to give higher kraft pulp yields at slightly lower $\mathrm{H}$ factors than top-log chips. All subsequent comparisons between PCT treatments and unthinned controls are made with 50-yearold stands. The 6-ft spacings seem to offer the greatest margin of \$2304 worth of NBSK per hectare harvested, while chips from the unthinned stands produce the lowest returns with a margin of $\$ 2073$ worth of NBSK per hectare harvested. Therefore, precommercial thinning to a nominal 6 -ft spacing could provide an additional \$231 of NBSK revenue per hectare. Interestingly, while NBSK margin increased from unthinned, through the 4 - $\mathrm{ft}$ spacing to the 6-ft spacing thinning treatments, it dropped by $\$ 169$ from the maximum to $\$ 2131$ worth of NBSK per hectare for the 8 -ft spacings. This was due to both a $2 \%$ drop in chip volume and a $4 \%$ lower wood density between the 8 - $\mathrm{ft}$ spacing and the 6-ft spacings, and suggests that a 6 - $\mathrm{ft}$ nominal spacing for PCT is near optimum for maximizing value recovered from 
Table 6. Cost of production, product sell price, and margin estimates for a tonne of northern bleached softwood kraft pulp (NBSK) and a tonne of $\mathbf{4 5}$ grammage newsprint made from a thermomechanical pulp. These two scenarios would use chip furnishes from one of the three PCT nominal spacings, or an unthinned control. All monetary values are in Canadian currency.

\begin{tabular}{|c|c|c|c|c|}
\hline & $\begin{array}{l}\text { Kraft } \\
\text { pulping }\end{array}$ & $\begin{array}{c}\text { TMP+ } \\
\text { newsprint }\end{array}$ & Comments & Reference \\
\hline $\begin{array}{l}\text { Cost of chips } \\
\text { (\$/oven dry tonne) }\end{array}$ & 140 & 140 & & Duchesne et al. 2103 \\
\hline $\begin{array}{l}\text { Delivered chip costs } \\
(10 \% \text { transportation } \\
\text { costs) }\end{array}$ & 154 & 154 & $\begin{array}{l}\text { Transport costs estimated as \% chip costs, assuming } \\
2 \mathrm{hr} \text { round trip, no backhaul and } \$ 1.3 / \mathrm{L} \text { of diesel. }\end{array}$ & $\begin{array}{l}\text { www.bcforestsafe.org/ } \\
\text { forestry_trucksafe/tools_- } \\
\text { truckers/calculator.html }\end{array}$ \\
\hline $\begin{array}{l}\text { Fibre costs }(\$ / t \text { of } \\
\text { Product) }\end{array}$ & & & $\begin{array}{l}\text { Kraft adjusted yields by PCT: } \\
\text { - adjusted for chip accepts content (86-90\%), }\end{array}$ & \\
\hline Unthinned & 395 & 173 & - average of Table 4 screened yield, subtract $3 \%$ & \\
\hline 4' spacings & 395 & 173 & (bleaching loss). & \\
\hline 6 'spacings & 402 & 173 & Newsprint adjusted yield by PCT & \\
\hline 8 ' spacings & 398 & 173 & $\begin{array}{l}\text { - adjusted for chip accepts content }(98 \%) \text {, } \\
\text { - TMP yield }(88 \%-89 \% \text { Fibre Cost } / \mathrm{t}=(1 / \mathrm{adj} \\
\text { yield)*delivered chip costs. }\end{array}$ & \\
\hline $\begin{array}{l}\text { Electrical power costs } \\
\text { (\$/t of product) }\end{array}$ & & & $\begin{array}{l}\text { NB power rates for high usage, commercial } \\
\text { enterprises. } \\
\text { (May } 2012 \text { rate quoted- } 0.068 \$ / \mathrm{kwh} \text { ) }\end{array}$ & $\begin{array}{l}\text { www.hydro.mb.ca/ } \\
\text { regulatory_affairs/ energy_ } \\
\text { rates/electricity/utility_- } \\
\text { rate_comp.shtml }\end{array}$ \\
\hline Unthinned & Not Applicable & 200 & & \\
\hline 4' spacings & Not Applicable & 191 & & \\
\hline 6' spacings & Not Applicable & 193 & & \\
\hline 8' spacings & Not Applicable & 201 & & \\
\hline $\begin{array}{l}\text { Other Production Costs } \\
\text { (\$/oven-dried tonne) }\end{array}$ & 265 & 245 & $\begin{array}{l}\text { Other production costs include chemicals and other } \\
\text { materials, labour, maintenance and administration } \\
\text { Estimated from unthinned stands and applied to } \\
\text { each PCT treatment (for kraft and newsprint). } \\
\text { Kraft: Estimated from RISI kraft pulping costs } \\
\text { (Q3-2005 -adjusted for inflation). } \\
\text { Newsprint: Company production costs (Q2-2012) - } \\
\text { less fibre and electrical power. }\end{array}$ & www.resolutefp.com \\
\hline Total Cost Of & & & Total cost of production $=$ & \\
\hline $\begin{array}{l}\text { Production } \\
\text { (\$/tonne of product) }\end{array}$ & & & $\begin{array}{l}\Sigma \text { (Fibre + Electrical Power+ Other production } \\
\text { costs). }\end{array}$ & \\
\hline Unthinned & 660 & 619 & & \\
\hline 4' spacings & 660 & 609 & & \\
\hline 6' spacings & 667 & 611 & & \\
\hline 8' spacings & 663 & 619 & & \\
\hline Selling Price (\$/tonne) & 780 & 624 & $\begin{array}{l}\text { Aug 02, } 2012 \text { USD prices for NBSK and Newsprint } \\
\text { (in CDN \$). }\end{array}$ & www.foex.fi/ \\
\hline Margin (\$/tonne) & & & $\begin{array}{l}\text { Margin is defined as the selling price less the total } \\
\text { cost of production for each PCT spacing and } \\
\text { unthinned stands. }\end{array}$ & \\
\hline Unthinned & 120 & 5 & & \\
\hline 4' spacings & 120 & 15 & & \\
\hline 6' spacings & 113 & 13 & & \\
\hline 8' spacings & 117 & 5 & & \\
\hline
\end{tabular}

the PCT generated chips when producing NBSK. Despite the increase in margin that is attributed to PCT, the longer pulping times (H-factor) noted between the chip furnishes from the 6-ft spacings and the unthinned control stands would have a detrimental effect on overall kraft mill productivity. Because of the slightly higher $\mathrm{H}$-factor required to pulp the 6-ft spacing slab-wood chips (relative to slab-wood chips from unthinned stands), a 1000 tpd kraft mill could expect to see a $1.4 \%$ loss in productivity, worth about $\$ 3$ million per annum. However, this would be compensated by a $1.3 \%$ reduction in chip consumption, due to higher pulp yields, which could save about $\$ 1.5$ million in chip costs per annum, leaving the mill a deficit of $\$ 1.5$ million per annum when using PCT chips. This loss could be reduced or possibly eliminated by optimizing mill operations to use PCT chip furnishes. However, such a break-even scenario would not be financially attractive to a kraft mill. Benefits 


\section{a) NBSK margin (\$/ha)}

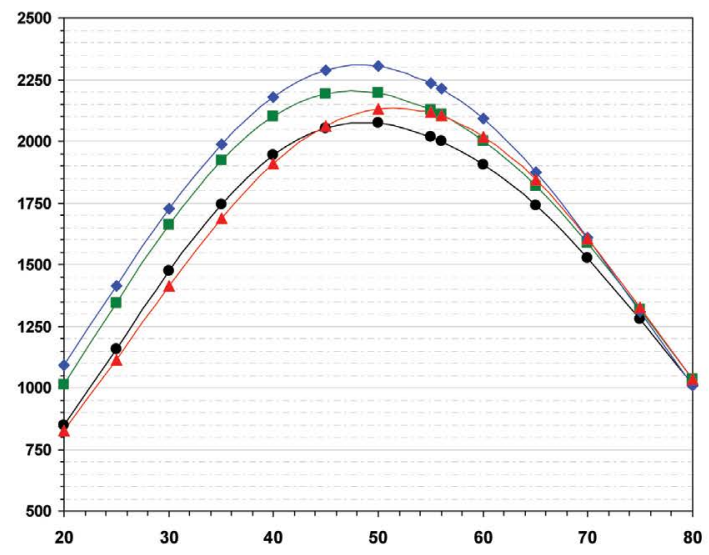

b) Newsprint margin $(\$ / \mathrm{ha})$

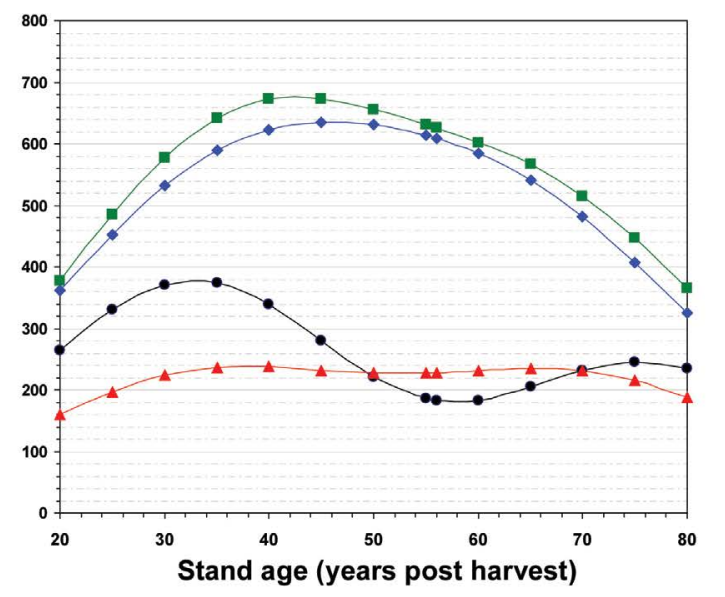

the proportion of slab-wood chips increases (Fig. 4b), the refining energy requirements (and costs) for the chip mixtures from the unthinned and 8-ft spaced stands increase. This accounts for the lower margins noted with these furnishes, relative to those from the $4-\mathrm{ft}$ and 6-ft spacings. Thermomechanical pulps are routinely made into paper products, rather than sold as pulps, and newsprint was selected as a base-case for this example. It is recognized that the economics of TMP production using these chip furnishes could change if other types of paper products were considered. Despite the comparatively lower margins, TMP pulping of PCT chips showed some distinct advantages relative to furnishes from unthinned stands. The lower refining energy costs for furnishes from the 4 - $\mathrm{ft}$ and 6 - $\mathrm{ft}$ spacings (relative to the control furnishes) could amount to a $\$ 2$ million per annum savings, under current pricing, for a 1000 tpd TMP mill. There would be little or no change in pulp quality relative to the pulps made from chips of unthinned stands and no capital expenditures would be needed to realize these savings. Furthermore, productivity losses due to lower wood densities from thinned stands could be offset by higher throughputs but this would be a mill-specific exercise.

\section{Conclusions}

The effects of precommercial thinning on the wood and fibre quality attributes of balsam fir relative to both chemical and thermomechanical pulping were assessed. From these studies, we have concluded that the long-term effects of PCT (nominal spacings between $4 \mathrm{ft}$ and $8 \mathrm{ft}$ [1.2 to $2.4 \mathrm{~m}$ ]) on pulp quality, for both kraft and TMP, are of little consequence. However, the effects on the economics of pulping can be significant and further optimization of pulping processes is warranted. As with lumber production, the greatest value extracted from chips used for kraft pulping occurred with the stands

realized by other segments of the supply chain would need to be shared (possibly via lower fibre costs), for a kraft mill to consider using chip furnishes from PCT stands.

An exercise analogous to the NBSK scenarios was performed on a 45 grammage newsprint made from thermomechanical pulps that used the chip furnishes from the PCT and unthinned control stands, the highest margins ( $\$ 443 / \mathrm{ha}$ ) were found with the chip furnishes from 40-year-old stands at a PTC spacing of $4 \mathrm{ft}$, and the lowest margins (\$390/ha) were with the unthinned stands, at the 0 -to 60 -year-old stand ages or young 8 -ft spaced stands across the 20- to 80 -year stand ages (Fig. 5b). The lower margins noted with furnishes from the unthinned and $8-\mathrm{ft}$ spaced stands were due to the higher specific refining energies of the slab-wood chips from these stands (Table 5). Slab-wood chips from the unthinned and 8 -ft spaced stands consume $6.8 \%$ and $4.9 \%$ more energy, respectively, to refine to a target freeness than slab-wood chips from the $4-\mathrm{ft}$ and 6-ft spaced stands. As nominally thinned to a 6-ft spacing, harvested approximately 50 years after overstory removal. This treatment gave the highest mass of chips with the greatest level of uniformity in wood quality, specifically with low levels of top-log chips. The nominal 6-ft spacing also resulted in the highest revenue generation per hectare of harvest for kraft pulping. The newsprint scenario evaluated showed that the highest margins were obtained in the 40 -year-old stands that were nominally spaced to $4 \mathrm{ft}$.

While TMP mills may benefit directly from the savings in refining energy that arise from using stands subjected to PCT, kraft operations would note a significant loss in revenue due to lower production rates. For PCT to be acceptable to a kraft by other stages of the value chain must be implemented to compensate the kraft mill for the loss in productivity related to the lower wood density and longer pulping times that would ensue. mill, some mechanism for the distribution of benefits realized 


\section{Acknowledgements}

Considerable funding for this work was provided by the $\mathrm{Ca}$ nadian Wood Fibre Centre of the Canadian Forest Service and the Transformative Technology Program of Natural Resources Canada. The contributions of FPInnovations - Pulp and Paper Division, were instrumental to the success of this project. Finally, we owe special thanks to Yonghoa Ni, Bill Francis, Gail Sherson, Michael Hoepting and Karen Jamieson for thoughtful comments and suggestions on earlier versions of this manuscript.

\section{References}

Drost, C., Y. Ni and D. Shewchuk. 2003. Effect of mature and juvenile wood from five wood species on kraft pulp strength. Pulp and Paper Canada 104(11): 33-36.

Duchesne, I., D.G. Pitt and F. Tanguay. 2013. Effects of precommercial thinning on the forest value chain in northwestern New Brunswick: Part 4 - Lumber production, quality and value. For. Chron. 89(4): 474-489.

Hatton, J.V. 1979. Chip quality analytical procedures. In J.V. Hatton (ed.). Chip Quality Monograph. pp. 313-314. Joint Textbook Committee of CPPA and TAPPI.

Hatton, J. 1997. Pulping and papermaking properties of managed second growth softwoods. TAPPI J. 80(10): 178-184.

Hussein, A., W. Gee, P. Watson and S. Zhang. 2006. Effect of precommercial thinning on residual sawmill kraft pulping and pulp quality in Balsam fir. Wood and Fibre Sci. 38(1): 179-186.

Keays, J. and J. Bagley. 1970. Digester assembly for precision pulping studies. TAPPI J. 53(10): 1935-1940.
Koga, S., S. Zhang and J. Bégin. 2002. Effects of precommercial thinning on annual radial growth and wood density in Balsam fir (Abies balsamea). Wood and Fibre Sci. 34(4): 625-642.

Milanova, E. and G. Dorris. 1994. On the determination of residual alkali in black liquors. Nordic Pulp Pap. Res. J. 9(1): 4-9.

[PAPTAC] Pulp and Paper Technical Association of Canada. 2013. Standard Testing Methods [online]. PAPTAC. Available at http://www. paptac.ca [Accessed 14 January 2013].

Pitt, D.G. and L. Lanteigne. 2008. Long-term outcome of precommercial thinning in northwestern New Brunswick: growth and yield of balsam fir and red spruce. Can. J. For. Res. 38: 592-610.

Pitt, D.G., L. Lanteigne, M.K. Hoepting, I. Duchesne, P. Bicho, J. Plamondon and G. Warren. 2013a. Effects of precommercial thinning on the forest value chain in northwestern New Brunswick: Part 6 - Estimating the economic benefits. For. Chron. 89(4): 502-511.

Pitt, D.G., L. Lanteigne, M.K. Hoepting and J. Farrell. 2013b. Effects of precommercial thinning on the forest value chain in northwestern New Brunswick: A fifty-year legacy of forest research continues. For. Chron. 89(4): 439-445.

Pitt, D.G., L. Lanteigne, M.K. Hoepting and J. Plamondon. 2013c. Effects of precommercial thinning on the forest value chain in northwestern New Brunswick: Part 1 - Roundwood production and stumpage value. For. Chron. 89(4): 446-457.

Plamondon, J., and D.G. Pitt. 2013. Effects of precommercial thinning on the forest value chain in northwestern New Brunswick: Part 2 - Efficiency gains in cut-to-length harvesting. For. Chron. 89(4): 458-463.

[TAPPI] Technical Association of Pulp and Paper Industry. 1994. Test Methods T200-T-1210. Technical Association of Pulp and Paper Industry, TAPPI Press, Atlanta, GA. Available at http://www.tappi.org [Accessed 14 January 2013].

Warren, G., P. Baines, J. Plamondon and D.G. Pitt. 2013. Effects of precommercial thinning on the forest value chain in northwestern New Brunswick: Part 3 - Incidence of root and butt decay. For. Chron. 89(4): 464-473. 